\title{
- КОМПЕНСАТОРНЕ ОСЯЯННЯ В РЕЛІГІЙНО-МІСТИЧНІЙ І ХУДОЖНІЙ КУЛЬТУРАХ (КУЛЬТУРОЛОГІЧНИЙ АНАЛІЗ «ВІДХОДУ ДРІБНИХ ДУМОК І СУЄТИ»)
}

\section{- Мурашкін Михайло Георгійович}

- Доктор фрілософрських наук, профресор,

ORCID: 0000-0001-7656-664X, e-mail: michailmurashkin@gmail.com,

Дніпропетровський національний університет внутрішніх справ, просп. Гагаріна, 26, Дніпро, Україна, 49000

\section{- Для цитування:}

Мурашкін, М.Г. (2019). Компенсаторне осяяння в релігійно-містичній і художній культурах (культурологічний аналіз «відходу дрібних думок і суєти»). Питання культурології, (35), 46-57. doi: https://doi.org/10.31866/2410-1311.35.2019.188784.

\section{- Анотація}

Метою статті є з'ясування і освітлення феномену компенсаторного осяяння, важливості і значимості такої його характеристики, як «відхід дрібних думок і суєти», що є в природі людини, відображене в релігійно-містичній і художньо-естетичній культурі. Важливості і значимості демонструються на прикладі зв'язку з трансцендентністю філософської культури, а також релігійно-містичної і художньо-естетичної культур. Методологія отримання нових знань ґрунтується на компаративному методі дослідження. При цьому зіставлені різні стани людини, а також дослідження таких культурних напрямків, як фрілософрський, релігійно-містичний, художньо-естетичний. Наукова новизна полягає в тому, що вперше розглядається такий феномен людської природи, як компенсаторне осяяння в зв'язку з трансцендентністю філософської культури, такими напрямками культури, як релігійномістичний і художньо-естетичний. Висновки. З'ясовано, що компенсаторне осяяння і його характеристика «відходу дрібних думок і суєти» $є$ невід'ємним феноменом природи людини. Він пов'язаний із процесом творчості при стадії «визрівання», на якій відбувається руйнація в людині її застарілої особистості. Це освітлено при демонстрації трансцендентності філософської культури, а також релігійно-містичної і художньо-естетичної культур.

- Ключові слова: компенсація; осяяння; трансцендентність; творчість; культура; релігійно-містична культура; художньо-естетична культура

\section{- Вступ}

Існує велика розбіжність розуміння трансцендентного у філософській культурі. Хоча трансцендентне - це узагальнююча категорія, і вона повинна охоплювати в своїй постійності значний зміст у природі людини. Однак трансцендентне 
абстрагується і відходить від людської природи. У XX столітті мова вже йде про те, що в трансцендентності відбувається відродження людської сутності, що помітив А. Н. Круглов (2010) у фрілософіії Карла Ясперса. Хоча це відродження можна було бачити протягом усієї історії в релігійно-містичній і художньоестетичній культурах.

Але виникає необхідність приблизити абстрактне розуміння трансцендентного до конкретних переживань людини задля встановлення нових особливостей тієї самої людини, її природи. На цьому шляху допомогою може бути компенсаторне осяяння людини, документальний опис якого ми маємо в багатьох напрямках культури: фрілософрській, релігійно-містичній, художньо-естетичній. Він торкається такої характеристики, як «відхід дрібних думок і суєти». Тому актуально встановити важливість і значимість цієї характеристики.

Аналіз публікацій показав, що попередні дослідження феномену компенсаторного осяяння вказують на зв'язок феномену, який досліджується з художньою психікою (Адлер, 1997, с. 106). Але немає розкриття того, що цей феномен природньо людський, як схильність людини до певних станів. Б. М. Теплов (1985) досліджував компенсаторні процеси при творчості у стані трансу, але що компенсувалося, не зазначав.

\section{- Мета статті}

Метою дослідження $є$ з'ясування і виявлення, чи $є$ френомен компенсаторного осяяння в природі людини, чи він приходить лише із впливом культурних цінностей. Адже компенсаторне осяяння яскраво відображено в релігійномістичній і художньо-естетичній культурі. Актуальність дослідження пов'язана з тим, що компенсаторне осяяння дає людині очищення від зайвих спонукань і потребує з'ясування, чи повинна людина прикладати зусилля по отриманню компенсаторного осяяння.

Також встановлено важливість і значимість характеристики «відходу дрібних думок і суєти» компенсаторного осяяння як трансцендентності, що $є$ в природі людини та відображено в релігійно-містичній і художньо-естетичній культурах.

\section{- Виклад матеріалу дослідження}

Існує природознавче розуміння людини як результату розвитку природи на Землі, як певного ступеня складності системи енергій і здатностей, системи, яка вже частково була наявна у попередніх формах високорозвинених тварин.

Але філософрька антропологія осмислює якісну специфріку людини, яка полягає у певній єдності тілесних, емоційно-чуттєвих і пізнавальних здатностей і можливостей, що надаються культурою соціального середовища. Коли ми торкаємось стану компенсаторного осяяння, то можна говорити про характеристику єдності, що виникає при зникненні усього зайвого. При виникненні компенсаторного осяяння маса дрібних думок, суєтних відходить (Мурашкин, 2006, с. 122). Тобто можна казати про руйнацію дрібних і суєтних думок, про руйнування ілюзій (Кристева, 2010, с. 138), помилок розуму (Бадмажапов, 1990, с. 147). Процес відходу дрібних думок і суєти, їх руйнації описаний у багатьох напрямках культури: фрілософрській, релігійно-містичній, художньо-естетичній. 
Дослідження важливості і значимості характеристики відходу дрібних думок і їх руйнування в компенсаторному осяянні потребують певної статистики, коли ми можемо фіксувати подібність у різних філософських школах, релігіях і містичних вченнях, а також у мистецтві. В даному дослідженні треба продемонструвати подібність характеристики «відходу дрібних думок, їх руйнування» і її проявів на великій площині біографрічних документальних матеріалів.

Збираючи біографічні документальні матеріали про руйнування як характеристику компенсаторного осяяння, треба враховувати той фракт, що самі філософри, релігійні діячі, містики і митці фріксували свої певні стани як руйнівні, які нищать їх особисті ілюзії, хибні думки, упередженості. Це й послуговує нам орієнтиром фіксувати певні стани як такі, що руйнують застаріле в свідомості людини.

Компенсаторне осяяння як предмет наших досліджень має таку особливість, як абсолютна спонтанність. Це те сакральне осяяння, яким не можна володіти (Кайуа, 2003, с. 253). Це вже вказує на те, що френомен, який ми досліджуємо, $\epsilon$ в природі людини.

Компенсаторне осяяння як реальне явище психічного життя людини підкоряється всезагальним законам діалектики. Згідно з таким законом діалектики, як заперечення заперечення, заперечується старе. Це пов'язано з тим, що творчий процес у людині проходить через певні фрази, такі як натхнення, уявлення, осяяння, нову ідею, логічну обробку цієї нової ідеї. Тут творчий процес включає в себе новину. Тобто однією із характеристик творчої роботи думки $є$ вирішення протиріч: створення нового неминуче пов'язане із запереченням старого (Спиркин, 1972, с. 195).

Творчий процес можуть супроводжувати транс і екстаз. Можна казати про творчість у трансподібному стані (Теплов, 1985, с. 268). А компенсаторне осяяння розглядається як певний вид трансу. Творчий же процес як отримання нових значень розмежовується на такі стадії: підготовка, визрівання, натхнення або осяяння і перевірка істинності (Роменець, 2004, с. 168-169). Тобто натхнення і осяяння можуть бути однією стадією (Вудвортс, 1981). А можливо, що натхнення переходить в екстаз у момент кульмінації творчого процесу - при осяянні (Ильин, 2011). Тут екстаз, а також і транс розуміються як супроводжуючі творчий процес. Коли ми кажемо про творчий процес і особисто про його стадію інсайту, тобто про осяяння як кульмінаційний момент, то цей кульмінаційний момент може бути і в стадії «визрівання».

У процесі тривалого визрівання концепції інсайти можуть виникати кілька разів, але не мати вирішального значення для розбудови концепції в цілому (Ильин, 2011). Вирішального значення може не мати і натхнення зі своїм переходом в екстаз або у транс. Натхнення може не давати успіху в творчості. Воно може бути лише поштовхом, стимулом до діяльності; більше того, лише стимулом, а не самою діяльністю. Натхнення не робить результатів, плодів творчості. Людина у творчому відношенні безплідна, хоча може переживати натхнення, екстаз, транс. Тобто натхнення може пройти без творчих результатів. Можна зазнати натхнення, екстазу і трансу без усілякого зовнішнього сліду. Далеко не геній може пережити такі ж натхнення, екстаз, транс, як і геній. Натхнення, ек- 
стаз і транс не означають змістовності, яка відділяє істину від хибності, добро від зла. Натхнення і екстаз, а також транс можуть проходити без наявності певного змісту (Гончаренко, 1991, с. 246-247). Та і сам інсайт, саме осяяння може не мати вирішального значення (Ильин, 2011). А такі френомени вже нагадують компенсаторне осяяння, трансцендентність у фрілософській культурі, самодостатність у релігійно-містичній і художньо-естетичній культурах. Адже самодостатність не має змістовності. Тут і відчуття щастя беззмістовне (Ясперс, 1997). Тут істини отримуються як суб'єктивна компенсація недостатнього, як певна гармонія через компенсаційні процеси.

Може бути і так, що в людині заперечується стара особистість взагалі, а не будь-який один частковий умовивід. Це антропологія особливо фріксує своїми документальними дослідженнями у філософській, релігійно-містичній, художньоестетичній культурах. Місія антропології полягає в документальному дослідженні світових культур і виявленні загальних основ людства (Морер, 2003, с. 22). Культура грає найважливішу роль, даючи матеріали для роздумів.

Тут документальні дослідження показують, що у фрілософській, релігійномістичній, художньо-естетичній культурах дуже часто особистість відкидається. В ній заперечується усе застаріле. Відкидаються усілякі норми і звичні уявлення, робиться перехід у «безґрунтовне» існування, існування 3 «ніщо» - це, напевно, єдина можливість «трансцендентної» свідомості опинитися за межами досвідного знання в ії̈ прагненні з'єднатися з Богом або Абсолютом (Висоцька, 2012, c. 66).

Філософська антропологія виділяє сутнісні ознаки людини. За Плеснером, однією з таких ознак $є$ ексцентричність - хитання між пошуком рівноваги зі світом (рівноваги, яка у людини відсутня) та намаганням подолати цю рівновагу, яка вже отримана і вже є в суспільстві і культурі. Компенсаторний транс і його момент осяяння можна вважати ідеальною рівновагою в людині на деякий час. Цей транс залишає в людині «слід», який дає їй можливість бути більш врівноваженою. Своєю врівноваженістю компенсаторне осяяння подібне до вищих переживань самоактуалізованої особистості. Ці переживання у людини можуть виникати доволі часто. При цьому вона втрачає характеристики свого застарілого «я», відбувається трансцендентність ії «я». Слід відзначити, що подібність із компенсаторним осяянням тут можна бачити в тому, що людина втрачає усю дріб'язковість своїх думок, мислення. У цьому відношенні вищі переживання синдрому самоактуалізації означень як широти (або не-дріб'язковості) $є$ проявом загальної характеристики, коли розкривається здібність піднестися над звичайністю, відректися від частковостей, розширити горизонти сприйняття і у підсумку подивитися на речі в перспективі (Маслоу, 2001, с. 233).

Стан компенсаторного осяяння приходить, коли людина починає змінюватись, коли відпадають певні обмеженості, які були перешкодою росту її духовного початку. При компенсаторному осяянні це відбувається поза волею людини, спонтанно. Спонтанність вказує на природність цього процесу. Але це може відбуватися і за власною волею, за допомогою медитації. Духовна практика може змушувати людину свідомо звільнитися від старих обмеженостей. При компенсаторному осяянні це відбувається спонтанно. Тобто буває, що це взагалі відбу- 
вається само собою, як природна частина розвитку людини (Гроф, 2001, с. 444). Це говорить про те, що подібні процеси вмонтовані в саму природу людини і демонструються релігійно-містичною і художньо-естетичною культурами.

В природу людини вмонтоване і просте забування. Якщо у людини те чи інше її відчуття не оживлюється впливом ззовні, то воно з часом забувається, зникає, руйнується. Поступово руйнація і знищення прихованих образів, спогадів відповідає процесу так званого «забування»; ми забуваємо уявлення, які не викликаються знову з їх прихованого стану відповідними відчуттями (Спенсер \& Циген, 1998, с. 434). При компенсаторному осяянні теж зникають відчуття, почуття, думки. Таке враження, що йде той самий процес забування, зникнення, руйнування. Але зникають і руйнуються відчуття, почуття і думки як головні. Вони стають просто не головними, другорядними. Зникають із поля зору як відхиляючі моменти. Частина з них руйнуються як хибні. Тобто ми бачимо, що увімкнутий творчий процес. Відходить не істинне, відходять помилковості. Це відбувається у людині стосовно її власного внутрішнього світу. Але це об'єктивно фріксують релігійно-містична і художньо-естетична культури.

Природне життя свідомості людини подібне до наукової діяльності. При цьому людина, за поглядами Анрі Пуанкаре, творить, винаходить - отже, виділяє, коротко кажучи, відбирає (Пекелис, 1986, с. 240). При компенсаторному осяянні подібні процеси призупиняються. Людина усвідомлює, що вона не туди зайшла, не те виділяє, не те відбирає, що істинний стан речей лежить в іншій площині. Людині відкривається ця інша площина як нове сприйняття, нове відчуття життя, яке передають релігійно-містична і художньо-естетична культури.

Компенсаторне осяяння подібне до тих творчих переживань, які проявляються в людині в ті моменти, коли те, що вона планувала і задумувала, виявляється основаним на хибних цінностях, коли те, що задумувалось, здавалося ціннісним втрачає усіляку цінність. Тоді проявляється творче переживання, яке шукає нові цінності, основи, які могли б стати головними при осмисленні життєвих завдань. Тут саме творче переживання виступає як цінність, оскільки воно руйнує все застаріле, змушує відійти всім дрібним думкам, що дозволить прийти новому змісту при перегляді людиною свого життєвого шляху, знайти той ціннісний ідеал, який дасть можливість людині бути самою собою. Подібні творчі переживання збігаються із компенсаторним осяянням, бо йде процес відмирання хибних цінностей. Відбувається викорінення зараженості душевного організму від відмираючих хибних цінностей (Василюк, 1984, с. 149).

За Геленом, фрілософська антропологія говорить, що людина біологічно непристосована. Біологічна непристосованість людини, про яку каже Гелен, усувається доцільною діяльністю зі створення штучного культурного середовища, суспільних інститутів. Але Гелен також розглядає людину, в природі якої надлишок спонукань. Тобто в людині $є$ і доцільна діяльність, і гра з її надлишком спонукань. Людина багатовимірна. 3 роками вона змінюється. Розглядаючи життя людини як реальний хід подій, із часом можна бачити, що в молоді роки вона заражається багатьма речами. Надлишок спонукань спостерігається у високому ступені. Навіть якщо необхідно задовольнити мінімум потреб, все одно людина в свої молоді роки виходить за межі необхідного. Значна частина спонукальних 
сил застосовується на те, щоб утримати довгі інтереси, тобто зафіксувати їх на противагу можливим контрінтересам (Гелен, 1988, с. 196-197). Однак із роками людина змінюється. Надлишок спонукань знижує свою інтенсивність. Зменшують ії і протиріччя у характері. В цьому відношенні у багатьох людей у старості відбуваються позитивні зміни - можна нерідко спостерігати умиротвореність, відхід від дріб'язкових інтересів життя, осмислення головних цінностей, адекватну переоцінку своїх бажань і можливостей, згладжування суперечливих рис характеру (Тибилова, 1991, с. 27). Тобто з роками дріб'язковість відходить. Людина концентрується на головному в своєму житті.

Людині властиво мати надлишок спонукань, у її природі надмір емоцій, думок. Надлишок емоційної енергії властивий психічному складу багатьох людей (Ассаджоли, 1997, с. 112). Але все це треба якось регулювати - і наплив емоцій, і наплив думок. Для цього існують медитативні практики, які скрізь вмонтовані в художньо-естетичну і релігійно-містичну культури, які виробляє людина. Від цього абстрагується філософрська культура в своєму розумінні трансцендентності. Так техніка усвідомленої медитації руйнує надлишкові роздумові процеси і моделі поведінки, які забирають дуже багато часу протягом дня (Берч \& Пенман, 2014, с. 72). Ця усвідомлена медитація присутня у фрілософрській категорії трансцендентності, в релігійно-містичній культурі. Про такий початок релігійно-містичної культури ми можемо прочитати у будь-якому споконвічному Святому Письмі: Ведах, Авесті, Трипітаці, Дао де цзіні, Торі, Біблії, Корані. Медитативна складова присутня у творах мистецтва. Людина, сприймаючи твір мистецтва, переживає катарсис. При цьому відбувається регулювання надлишку емоційної енергії (Ассаджоли, 1997, с. 112). У художньо-естетичній культурі для цього існує фрорма. Тут найважливішим способом, за допомогою якого художник-митець досягає катарсичного афекту, є знищення змісту формою (Петрушин, 2008, с. 89). Тобто мова йде про руйнування всього надлишкового в людині з метою оволодіння собою. Для цього існують певні способи медитативної практики, якими насичена релігійно-містична культура, присутні в художньо-естетичній культурі, розуміння яких вкладається в категорію трансцендентної фрілософрської культури. Медитації ми можемо спостерігати як невід'ємний компонент у таких видах мистецтва, як медитативна музика, медитативна лірика.

Доцільно відходити від такої діяльності, яка може накопичувати в людині неврівноваженість. А різні компенсаторні процеси існують, щоб врівноважити і гармонізувати психічні прояви людини. На те й існує компенсаторний транс. Компенсація безсвідома і впливає на свідому діяльність, регулює її безсвідомо (Юнг, 1995, с. 532).

За Карлом Марксом, сутність людини - це сукупність усіх суспільних відносин. Але людина своєю творчістю і порушує застарілі суспільні відносини в зв'язку з тим, що навколишній світ змінюється, і конче потрібні нові. В цій зміні важливу роль грає трансгресивне мислення людини, що виходить за межі певних правил, які вже застарілі і потребують перегляду. Ці правила руйнуються задля нового. В цій руйнації важливу роль відіграє компенсаторний транс, який супроводжує творчий процес. 
Важлива особливість компенсаторного осяяння і його характеристики «відходу дрібних думок і суєти», подібна до трансцендентності фрілософа, яка спостерігається як у містика, так і у митця, - це процес руйнування істин, що вже існують у людини, в її свідомості. В містицизмі взагалі існує центральний символ - це смерть як знак для досвіду, який порушує попередні структури свідомості (Аверинцев, 2010, с. 579). Це порушення $є$ невід'ємною частиною творчого процесу. Коли у людини в її свідомості твориться нове, то обов'язково порушується старе, застаріле, яке віджило своє. Процес руйнації відбивається у відчуттях певного стану, трансцендентного «вищого стану свідомості». Це відчуває не тільки філософ, містик, але і митець. Процес руйнації відбивається не тільки в суб'єктивних станах митця, а і взагалі у мистецтві як культурному напрямку. Особливо музика прагне руйнації, руйнації усілякого роду, вгасання, зламу (Делёз \& Гваттари, 2010, с. 498). Але не тільки музика, а й живопис передає процеси руйнації. Руйнація ілюзій перетворюється на красу, що особливо чітко відчувається в жіночих портретах (Кристева, 2010, с. 138). Митець відображає руйнацію не просто ілюзій у собі, а й у самій культурі. В цьому відношенні лірика не стільки виражає відчуття поета, скільки робить поезію митця зброєю, яка руйнує культуру (Каллер, 2006, с. 84), її ілюзорні істини. Але найголовніше, що є в цьому процесі і спостерігається в трансцендентності, - це те, що йде «відхід дрібних думок і суєти». Тобто відкидається дріб'язкове «я» (Судзуки \& Кацуки, 1993, с. 488). Це відкидання фріксують твори релігійно-містичної і художньо-естетичної культури.

\section{- Висновки}

При порівнянні різних станів людини, а також при освітленні різних напрямків культури встановлено, що компенсаторне осяяння і його характеристика «відхід дрібних думок і суєти» $є$ френоменом людської природи, творчих процесів. Це стадія «визрівання» у творчому процесі. Вона зводиться до руйнування цінностей попередніх структур свідомості, застарілої людської особистості. Наступна стадія творчого процесу - це «інсайт», де оновлюються цінності структур свідомості, людська особистість і її структури свідомості. Але ця стадія з'являється кілька разів і при «визріванні», не маючи особливого вирішального значення. Цей інсайт у філософській культурі відображається в категорії трансцендентності. Компенсаторне осяяння і його характеристика «відхід дрібних думок і суєти» фігурують і в релігійно-містичній, і в художньо-естетичній культурах як значимі і важливі. Значимість і важливість пов'язані з тим, що феномен компенсаторного осяяння стосується ширшого, ніж конкретні завдання для творчості, перетворення особистості людини, що оновлюється людина, зміст таких культурних напрямків, як фрілософрський, релігійно-містичний, художньо-естетичний. Сучасність потребує оновлення.

В результаті дослідження доведено, що компенсаторне осяяння і така його характеристика, як «відхід дрібних думок і суєти», $є$ схильністю в природі людини, але реалізується вона спонтанно за впливу певних культурних надбань. $\mathrm{Pe}-$ зультати дослідження були отримані через компаративний метод при порівнянні різних станів людини і проявів культурного середовища. 


\section{- Список використаних джерел}

Аверинцев, С.С. (2010). Мистика. В Новая ффилософьская энциклопедия (Т. 2). Москва: Мысль.

Адлер, А. (1997). О нервическом характере. Санкт-Петербург: Университетская книга. Ассаджоли, Р. (1997). Психосинтез (А.П. Хомик, Пер.). Москва: Рефрл-бук; Киев: Ваклер. Бадмажапов, Ц.-Б. (1990). О соотношении «психодогического» и «эстетического» В буддистской иконографической традиции. В Буддизм и культурнопсихологические традищии народов Востока (с. 138-148). Новосибирск: Наука.

Берч, В., \& Пенман, Д. (2014). Осознанная медитация: Практическое пособие по снятию боли и стресса (Ю. Цыбышева, Пер.). Москва: Манн, Иванов и Фербер.

Василюк, Ф.Е. (1984). Психология переживания (анализ преодоления критических ситуаций). Москва: Издательство Московского университета.

Висоцька, О.Є. (2012). Етика взаємодії суспільства з природою: морально-ціннісні основи екологічної культури. Дніпропетровськ: Акцент ПП.

Вудвортс, Р. (1981). Этапы творческого мышления. В Ю.Б. Гиппенрейтер, \& В.В. Петухов (Ред.), Хрестоматия по общей психологии. Психология мышления (с. 255-257). Москва: Издательство Московского университета.

Гелен, А.О. (1988). О систематике антропологии. В П.С Гуревич, \& Ю.Н. Попов (Ред.), Проблема человека в западной философии (с. 152-201). Москва: Прогресс.

Гончаренко, Н.В. (1991). Гений в искусстве и науке. Москва: Искусство.

Гроф, С. (2001). Тёмная ночь души. В К.В. Сельченок (Сост.), Психология религиозности и мистицизма (с. 422-461). Минск: Харвест; Москва: АСТ.

Делёз, Ж., \& Гваттари, Ф. (2010). Капитализм и шизофррения: Тысяча плато. Екатеринбург: У-Фактория; Москва: Астрель.

Ильин, Е.П. (2011). Психология творчества, креативности, одарённости. СанктПетербург: Питер.

Кайуа, Р. (2003). Мифр и человек. Человек и сакральное (С.Н. Зенкин, Пер.) Москва: ОГИ. Каллер, Д. (2006). Теория литературы: краткое введение. Москва: Астрель; АСТ.

Кристева, Ю. (2010). Черное солнце: депрессия и меланхолия. Москва: Когито-Центр.

Круглов, А.Н. (2010). Трансцендентное. В Новая фрилософрская энциклопедия (Т. 4). Москва: Мысль.

Маслоу, А.Г. (2001). Мотивация и личность (А.М. Татлыбаева, Пер.). Санкт-Петербург: Евразия.

Mopep, В. (2003). Антропологія. В Ч. Вінквіст, \& В. Тейлор (Ред.), Енциклопедія постмодернізму (с. 22). Київ: Основи.

Мурашкин, М.Г. (2006). Записи 2000 года (Я...). Дніпропетровськ: СІЧ.

Пекелис, В.Д. (1986). Твои возможности, человек! Москва: Знание.

Петрушин, В.И. (2008). Музыкальная психология. Москва: Академический Проспект; Трикста.

Роменець, В.А. (2004). Психологія творчості (3-тє вид.). Київ: Либідь.

Спенсер, Г., \& Циген, Т. (1998). Основания психологии. Физиологическая психология в 14 лекциях. Москва: АСТ.

Спиркин, А.Г. (1972). Сознание и самосознание [Монография]. Москва: Политиздат.

Судзуки, Д., \& Кацуки, С. (1993). Дзэн-Буддизм: Основы Дзэн-Буддизма. Практика Дзэн. Бишкек: МП "Одиссей". 
Теплов, Б.М. (1985). Конспекты и комментарии к книге А. Анастази "Дифференциальная психология". В Б.М. Теплов, Избранные труды (Т. 2, с. 247-279). Москва: Педагогика.

Тибилова, А.У. (1991). Восстановительная терапия психически больных позднего возраста. Ленинград: Медицина.

Юнг, К. (1995). Психологические типы. Санкт-Петербург: Ювента; Москва: Прогресс.

Ясперс, К. (1997). Общая психопатология. Москва: Практика.

\section{- References}

Adler, A. (1997). O nervicheskom kharaktere [On the nervous nature]. St. Petersburg: Universitetskaia kniga [in Russian].

Assagioli, R. (1997). Psikhosintez [Psychosynthesis] (A.P. Khomik, Trans.). Moscow: Refl-buk; Kyiv: Vakler [in Russian].

Averintcev, S.S. (2010). Mistika [Mystic]. In Novaia filosofskaia entciklopediia [New Philosophical Encyclopedia] (Vol. 2). Moscow: Mysl [in Russian].

Badmazhapov, Tc.-B. (1990) O sootnoshenii "psikhodogicheskogo" i "esteticheskogo" $\checkmark$ buddistskoi ikonograficheskoi traditcii [On the correlation of "psychological" and "aesthetic" in the Buddhist iconographic tradition]. In Buddizm i kulturnopsikhologicheskie traditcii narodov Vostoka [Buddhism and cultural-psychological traditions of the nations of the East] (pp. 138-148). Novosibirsk: Nauka [in Russian].

Berch, V., \& Penman, D. (2014). Osoznannaia meditatciia: Prakticheskoe posobie po sniatiiu boli i stressa [Conscious Meditation: A Practical Guide to Relieving Pain and Stress] (lu. Tcybysheva, Trans.). Moscow: Mann, Ivanov i Ferber [in Russian].

Caillois, R. (2003). Mif i chelovek. Chelovek i sakralnoe [Myth and man. Man and the Sacred] (S.N. Zenkin, Trans.) Moscow: OGI [in Russian].

Deleuze, G., \& Guattari, F. (2010). Kapitalizm i shizofreniia: Tysiacha plato [Capitalism and Schizophrenia: A Thousand Plateaus]. Ekaterinburg: U-Faktoriia; Moscow: Astrel [in Russian].

Gelen, A.O. (1988). O sistematike antropologii [On the systematics of anthropology]. In P.S. Gurevich, \& lu.N. Popov (Eds.), Problema cheloveka v zapadnoi filosofii [The Problem of Man in Western Philosophy] (pp. 152-201). Moscow: Progress [in Russian]. Goncharenko, N.V. (1991). Genii v iskusstve i nauke [Genius in art and science]. Moscow: Iskusstvo [in Russian].

Grof, S. (2001). Temnaia noch dushi [The dark night of the soul]. In K.V. Selchenok (Comp.), Psikhologiia religioznosti i mistitcizma [Psychology of religiosity and mysticism] (pp. 422-461). Minsk: Kharvest; Moscow: AST [in Russian].

Ilin, E.P. (2011). Psikhologiia tvorchestva, kreativnosti, odarennosti [Psychology of creativity, creativity, talent]. St. Petersburg: Piter [in Russian].

Jaspers, K. (1997). Obshchaia psikhopatologiia [General psychopathology]. Moscow: Praktika [in Russian].

Jung, C. (1995). Psikhologicheskie tipy [Psychological types]. St. Petersburg: luventa; Moscow: Progress [in Russian].

Kaller, D. (2006). Teoriia literatury: kratkoe vvedenie [Literature Theory: A Brief Introduction]. Moscow: Astrel; AST [in Russian].

Kristeva, lu. (2010). Chernoe solntce: depressiia i melankholiia [Black sun: depression and melancholy]. Moscow: Kogito-Tcentr [in Russian]. 
Kruglov, A.N. (2010). Transtcendentnoe [Transcendental]. In Novaia filosofskaia entciklopediia [New Philosophical Encyclopedia] (Vol. 4). Moscow: Mysl [in Russian].

Maslow, A.H. (2001). Motivatciia i lichnost [Motivation and personality] (A.M. Tatlybaeva, Trans.). St. Petersburg: Evraziia [in Russian].

Morer, V. (2003). Antropolohiia [Anthropology]. In Ch. Vinkvist, \& V.Teilor (Eds.), Entsyklopediia postmodernizmu [Encyclopedia of Postmodernism] (p. 22). Kyiv: Osnovy [in Ukrainian].

Murashkin, M.G. (2006). Zapisi 2000 goda (la ...) [Records of 2000 (I ...)]. Dnipropetrovsk: SICh [in Russian].

Pekelis, V.D. (1986). Tvoi vozmozhnosti, chelovek! [Your capacity, man!]. Moscow: Znanie [in Russian].

Petrushin, V.I. (2008). Muzykalnaia psikhologiia [Musical psychology]. Moscow: Akademicheskii Prospekt; Triksta [in Russian].

Romenets, V.A. (2004). Psykholohiia tvorchosti [Psychology of creativity] (3rd ed.). Kyiv: Lybid [in Ukrainian].

Spenser, H., \& Ziehen, T. (1998). Osnovaniia psikhologii. Fiziologicheskaia psikhologiia v 14 lektciiakh [Foundations of Psychology. Physiological Psychology in 14 lectures]. Moscow: AST [in Russian].

Spirkin, A.G. (1972). Soznanie i samosoznanie [Consciousness and Identity] [Monograph]. Moscow: Politizdat [in Russian].

Suzuki, D., \& Katsuki, S. (1993). Dzen-Buddizm: Osnovy Dzen-Buddizma. Praktika Dzen [Zen Buddhism: The Basics of Zen Buddhism. Zen practice]. Bishkek: MP "Odissei" [in Russian].

Teplov, B.M. (1985). Konspekty i kommentarii k knige A. Anastazi "Differentcialnaia psikhologiia" [Summaries and comments on the book of A. Anastasi "Differential Psychology"]. In B.M. Teplov, Izbrannye trudy [Selected Works] (Vol. 2, pp. 247-279). Moscow: Pedagogika [in Russian].

Tibilova, A.U. (1991). Vosstanovitelnaia terapiia psikhicheski bolnykh pozdnego vozrasta [Restorative treatment for the mentally ill of advanced age]. Leningrad: Meditcina [in Russian].

Vasiliuk, F.E. (1984). Psikhologiia perezhivaniia (analiz preodoleniia kriticheskikh situatcii) [Psychology of experience (analysis of overcoming critical situations)]. Moscow: Izdatelstvo Moskovskogo universiteta [in Russian].

Vudvorts, R. (1981). Etapy tvorcheskogo myshleniia [Stages of Creative Thinking]. In lu.B. Gippenreiter, \& V.V. Petukhov (Eds.), Khrestomatiia po obshchei psikhologii. Psikhologiia myshleniia [A reading book on general psychology. Psychology of thinking] (pp. 255-257). Moscow: Izdatelstvo Moskovskogo universiteta [in Russian].

Vysotska, O.Ye. (2012). Etyka vzaiemodii suspilstva z pryrodoiu: moralno-tsinnisni osnovy ekolohichnoi kultury [Ethics of interaction of society with nature: moral values of ecological culture]. Dnipropetrovsk: Aktsent PP [in Ukrainian]. 


\section{- REDEEMING INSIGHT IN RELIGIOUS-MYSTICAL} AND ART-AESTHETIC CULTURES (CULTURAL ANALYSIS
OF "SHALLOW THOUGHTS AND VANITY WITHDRAWAL")

\section{- Mykhailo Murashkin}

- Doctor of Philosophy, Professor, ORCID: 0000-0001-7656-664X, e-mail: michailmurashkin@gmail.com, Dnipropetrovsk State University of Internal Affairs, Dnipro, Ukraine

\section{- Abstract}

The purpose of the article is to find out and clarify the phenomenon of redeeming insight, the importance and significance of such characteristics as "shallow thoughts and vanity withdrawal", which is in the nature of man, reflected in religious-mystical and art-aesthetic culture. The importance and significance are exemplified by the connection with the transcendence of philosophical culture as well as religious-mystical and art-aesthetic cultures. The research methodology for acquiring new knowledge is based on a comparative research method. At the same time, different states of man are compared, as well as studies of such cultural trends as philosophical, religious-mystical, and artistic-aesthetic. The scientific novelty is that for the first time such a phenomenon of human nature is considered as a redeeming insight in connection with the transcendence of philosophical culture, in such fields of culture as religious-mystical and artistic-aesthetic. Conclusions. It has been found that the redeeming insight and its characteristic "shallow thoughts and vanity withdrawal" is an integral phenomenon of human nature. It is associated with the process of creativity in the stage of "ageing", which destroys the person in his demoded personality. This is informed at demonstrating the transcendence of philosophical culture, as well as religious-mystical and art-aesthetic cultures.

Keywords: redeeming; insight; transcendence; art; culture; religious-mystical culture; artistic and aesthetic culture 


\section{- КОМПЕНСАТОРНОЕ ОЗАРЕНИЕ В РЕЛИГИОЗНО- МИСТИЧЕСКОЙ И ХУДОЖЕСТВЕННОЙ КУЛЬТУРАХ (КУЛЬТУРОЛОГИЧЕСКИЙ АНАЛИЗ «УХОДА МЕЛКИХ МЫСЛЕЙ И СУЕТЫ»)}

\section{- Мурашкин Михаил Георгиевич}

- Доктор фолософрских наук, профрессор, ORCID: 0000-0001-7656-664X, e-mail: michailmurashkin@gmail.com, Днепропетровский национальный университет внутренних дел, Днепр, Украина

\section{- Аннотация}

Целью статьи является выяснение и освещение феномена компенсаторного озарения, важности и значимости такой его характеристики, как «уход мелких мыслей и суеты», содержащегося в природе человека. Важность и значимость демонстрируются на примере связки с трансцендентностью философской культуры, а также религиозномистической и художественно-эстетической культур. Методология обретения новых знаний основывается на компаративном методе исследования. При этом сопоставлены различные состояния человека, а также исследования таких культурных направлений, как фрилософрское, религиозно-мистическое, художественно-эстетическое. Научная новизна заключается в том, что впервые рассматривается такой френомен человеческой природы, как компенсаторное озарение в связи с трансцендентностью философской культуры с такими направлениями культуры, как религиозно-мистическое и художественноэстетическое. Выводы. Выяснено, что компенсаторное озарение и его характеристика «уход мелких мыслей и суеты» является неотьемлемым феноменом природы человека. Он связан с процессом творчества в стадии «вызревания», на которой происходит разрушение в человеке его устаревшей личности. Это освещено при демонстрации трансцендентности философрской культуры, а также религиозно-мистической и художественно-эстетической культур.

Ключевые слова: компенсация; озарение; трансцендентность; творчество; культура; религиозно-мистическая культура; художественно-эстетическая культура 